\title{
If You Build It, Will They Come? An Inside Look at a Small Art Market
}

\author{
Toby A. Ten Eyck ${ }^{*}$, Jacqueline Kaltz, Caitlin Annatoyn, Ashlee Brininstool and Susan Yousif
}

Department of Sociology and Michigan State University Extension, Michigan State University, USA

\begin{abstract}
Discussions of art are often linked to cities such as New York, London, and Paris, though art is also negotiated within small markets. This paper investigates the ways in which gallery owners and artists in a small art market think about the role of art in urban sustainability and social engagement. Through semi-structured interviews, we discovered that many individuals were finding it difficult to maintain an economically feasible business, while also saying that the community supported the arts at various levels. Much of the art that would be considered socially engaged consisted of political caricatures, and typically did not sell very well. We also found that the market functioned as a zero sum game for many of the actors, though there was little evidence that this needed to be the case. Finally, surveys results from two socially engaged art shows are provided to show how patrons for the arts think about the economic importance of the arts at the local level.
\end{abstract}

\section{INTRODUCTION}

The arts can have a major impact on the economic vitality of an urban area [1]. For this reason, numerous cities have developed art-friendly districts or festivals to draw people into their urban cores [2]. The value of art, however, is not fixed but dependent on the networks in which it moves $[3,4]$, including the size and history of the market where it is being shown. Art that sells for thousands of dollars in New York or Los Angeles may only garner a few hundred dollars in a smaller Midwest or Southern town, or go completely unnoticed, ridiculed, or even censored by local officials. ${ }^{\wedge}$

This paper is about how people engaged in art businesses negotiate a small, Midwest art market. Entering a small market as an artist can be intimidating, not only because his/her art will be put into a public arena where his/her identity may be known, but because the art marketing literature is often geared toward larger cities. Barnes [5], for example, tells the emerging artist that a good way to succeed is to move to New York City. Even places like New York, however, have limited carry capacities for the arts, and the cost to move oneself and one's art to a new area can be prohibitive given that there are no guarantees for success and recouping one's expenditures. In addition, we assume that some artists enjoy their small hometowns and want to sell their work locally.

Our theoretical grounding stems from work on the intersection of culture and economics, as well as the idea that art is an active reflection and interpretation of society. We found this to be the case when we began interviewing individuals involved in the making and selling of art in one Midwest city. Our categorization of this as a small art market

*Address correspondence to this author at the Department of Sociology, 316 Berkey Hall, Michigan State University, East Lansing, MI 48824, USA; Tel: 517-353-8671; E-mail: teneyck@msu.edu

${ }^{\wedge}$ Censorship and ignored art also takes place in larger markets. The point is that not all markets are the same, and many smaller markets cannot support large price tags on art, or at least not in the same abundance as a larger market. is based the fact that it is not within the top 100 metropolitan statistical areas, the population is less that 500,00, and there are approximately eleven galleries operating in the area. We turn now to a discussion of what is meant by art being an active reflection of society.

\section{THEORETICAL AND CONCEPTUAL FRAME- WORK}

Social scientists have studied a number of aspects of art, including economics $[4,6]$ and class differentiation through consumption [7, 8]. Dewey ([9] p. 326), in discussing esthetics, argued that, "[e]sthetic experience is a manifestation, a record and celebration of the life of a civilization, a means of promoting its development, and is also the ultimate judgment upon the quality of a civilization." Does this mean that France was full of idealistic landscapes and friendly people enjoying picnics on sunny afternoons while the Impressionists were painting? This seems to be the current interpretation of classic Impressionism, though King [10] argues that the early Impressionists (e.g., Monet, Manet) were ridiculed for their use of vibrant colors and loose brushwork. The reinterpretation of their work (and history) has been negotiated within the power centers of various political and art circles.

This leads to the question of what is meant when it is said that art is a reflection of society. For some, art is expected to be a representation or interpretation of nature. For others, such as the Dadaists [11] and surrealists [12], art was meant to challenge social boundaries or display one's own psyche with the hope of shocking the masses. Much of what we know of these artists and movements, however, comes from art that has hung in museums and galleries in places like Paris, Berlin, and New York. Very little is known, on the other hand, of artists who market their wares in smaller cities and towns, though these areas can have vibrant art communities [13]. Does this art, as well as support for the arts in a smaller community, reflect the tastes and cultural knowledge of the area? We believe it does, though the reflection is not simply imitative. The reality of an art market 
is constructed through a process of the making, displaying, and buying of art [4], and in a small market where artists are closely aligned with their galleries, this process is manifest in a number of ways.

The small market, in fact, can provide a microcosm of the link between culture and economics. DiMaggio [6] has noted that culture is more than arts and letters, and should include "shared cognitions, values, norms, and expressive symbols . . . ." For DiMaggio [6, 14] the typical distinction between culture and economics is often overstated. Our economic systems grow out of cultural practices, which, in turn, impact what cultural practices become reified. In a large art market, such as New York, galleries can use this knowledge to cater to specific audiences (e.g., modern art, Impressionism, realism, classical art, outsider art, ceramics there is even a gallery in Chicago that specializes in new surface textures), and use specific media outlets for promotional purposes. The trick is to find the right promotional hook and outlet to bring in customers. In a smaller market where media outlets are limited, galleries and artists - unless independently wealthy - will find themselves side-by-side with other galleries and businesses offering completely different services in the daily newspaper. Consumers for specific types of art may be living in the area as well, but it is likely that their numbers are so small that a gallery that carries only one genre will be hard pressed to maintain an economically feasible presence [3].

The process seems to be dialectic, where we focus on objectification [15]. The objectification of art - its hanging in galleries, as well as the justification for hanging that art and the exchange component of art between galleries, artists, and customers, help to understand the workings of the market. To focus specifically on the making of art tells us little about how that art is negotiated within a small market, as the artists may seek to sell their works elsewhere. The consumption of art is also not necessarily local. Many of the gallery owners we interviewed mentioned that locals who were willing and able to purchase art did so when traveling outside the area. As mentioned by Fine [16], buying art is as much about buying a story as it is about the piece itself. To say that a piece is from New York or South Africa seems to be a better story than saying the piece was purchased at the local artisan market. This provides the gallery owner (and artists) in large markets a wider repertoire of stories to draw on to make the sale. For example, the art can be sold by linking it to a location ("you're buying New York art"), as an investment ("if I'm purchasing this in New York, it will be worth even more later"), or for the artist ("only famous artists display their work in New York"). Within the smaller market, the lack of renown for a location forces stories to be tied more directly to the artist or the piece of art. In economic terms, gallery owners and artists in these smaller markets become the conduit between the art and the customer, where in the larger markets the gallery owners and artists are only one of many tools that can be used to link a piece of art to a customer.

Objectification is the point in the social dialectic in which an action is made viewable to others [15]. The action is then judged which, in turn, can lead to justifications for specific actions. While many of us seek confirmatory judgments from significant others [17], we are often questioned when our action seems inappropriate. At this point, we may be asked to provide a justification for the action. Boltanski and Thévenot [18-20] developed a conceptual framework for thinking about these kinds of justifications which consist of six worlds or orders of worth. Each of the worlds consists of four aspects - worth of evaluation, format of relevant information, elementary relation, and human qualification. Importantly, the authors emphasize that actors do not reside in any of these worlds, but rather appeal to one or more of them as needed to justify their positions [21]. The inspirational world is defined by grace, passion, and creativity, while the opinion world is defined by recognition and celebrity status. Solidarity and equality are part of the civic world, while the market arena is centered on monetary exchange and desire. The industrial world needs to be functional and efficient, and finally, the domestic world is built on trust and authority, where tradition is often passed down orally from one "generation" to the next. We assume gallery owners to mainly look to the market order of worth to justify their actions, though this may be tempered to some extent by the creative sphere of which they are a part (such as looking for new artists and justifying such a move through an inspirational order of worth).

When conflicts arise, actors appeal to these various worlds, often drawing from more than one world. For example, an artist who is inspired through the nurturing of creativity may not want to fit into the solidarity model promoted by her government [22], or may argue that her art is inspired about concerns with the civic structures in which she is embedded. The gallery owner, who is concerned with monetary exchange, may find the rants of the local critic who is seeking recognition -- opinion order of worth -- to be detrimental for business. In fact, complete consensus across all of these worlds is likely to be an exception, which seems to be the case since at least the Impressionist movement of the mid- to late 1800 s [10].

Justifications provide evidence for something, in this case art. When asked about art in a local area, gallery owners and others had to justify their own existence as a business interest, as well as what they were selling (or in some cases producing). This is an active interpretation of the workings of the market, as well as a perception of local aesthetic tastes. Small markets are spaces where both art preferences are easily noted, and where networks of artists, gallery owners, and customers are put on display.

This, of course, does not mean the decisions made within the galleries are right in a marketing sense. Almost everyone we spoke with had stories of how close they had come at some point to shutting their doors. Fine [16] notes that for some people the discussion of art and money in the same breadth is sacrilegious, but that art must have markets to survive, even going so far as to say that "[ $\mathrm{t}]$ he market is the means through which Western societies organize artistic life." If we attach this to DiMaggio's [6] contention that markets are reciprocal and depend on trust, we begin to see the need to understand how art markets are not just about art, but about relationships that grow out of interpretations of past experiences. These experiences provide the context for new purchases (real or perceived), as customers come to expect certain products and personalities at various galleries, 
and gallery owners try to gain a sense of customer needs and desires to maintain their business.

It should be noted that we are not looking at actual prices, though other work in this area is relevant [23]. Shubik [24], echoing Becker [4], contends that the value of art is based on norms within cultural arenas, eschewing scientific validity (with the possible exception of validating provenance). What is important to note about the small market is that while economic decisions do play a role, it is a combination of art and community norms that help set prices. If there is little demand in a small market for art that is selling for thousands of dollars in New York, the small market price tag - if the gallery is interested in selling the art - will likely be a reflection of that market, and not the going rate in New York. Still, the price on such a piece would probably be higher than something from a local artist who does not have an extensive portfolio. In addition, if a market is inundated with art fairs where prices are very low, it will be hard for a gallery to sell at higher prices, especially if the artists at the fairs are the same artists showing their work in the galleries. We heard stories of artists telling potential customers in the galleries to wait until after the show to purchase the art, as the artist would be able to sell it cheaper. This was due to the fact that many galleries charged a $50 \%$ commission, so an artist selling a piece for $\$ 1000$ would only get $\$ 500$ if she sold it in the gallery. The same artist could give the customer a "bargain" by selling it for $\$ 750$ after the show was over, pocketing an extra $\$ 250$ while saving the customer the same amount of money.

We were also interested in businesses that were in close proximity to the galleries. In the area we studied, one could find restaurants, cafes, boutiques, and other small shops which were hoping to sell to the same consumers. According to Evans [25], the arts do play a part in revitalizing urban areas, as people with money are drawn to the arts, and some will include a meal or do other shopping when visiting inner city galleries. There seems to be, however, very little systematic information on how such areas are negotiated. Do people come to the galleries and then buy a meal, or are they drawn to the restaurants in the area and then see the galleries? Our interviews show that many within the art community are not cognizant of what draws their customers to the art district.

The other component we looked was the display of socially engaged art. This is art that takes on specific social issues, such as violence, sexism, racism, and colonization. One of the better known pieces in this genre is Picasso's Guernica, which depicts an attack on the Spanish town of the same name in 1937 during the Spanish Civil War. Some have argued that the attack was a rehearsal for the Nazi's Blitzkrieg tactics, as Guernica was not a strategic location in the Civil War. Picasso had been commissioned by the Spanish government prior to the attack to create a piece that would depict some aspect of Spain's history, which led to a debate at the time about the appropriateness of the painting.

While Guernica and other cultural products have gained a popular following, little is known about how such work that is created by local artists is received (by both galleries and consumers) in smaller markets. Atkins and Mintcheva [26] provide a number of examples of growing concerns around censorship from both external sources (such as government and religious organizations) and within the art community itself, as artists are fearful of losing customers by creating controversial pieces. By discussing this aspect of art with local gallery owners and artists, we hope to develop a better understanding of the potential to use gallery space as a launching point and venue for political activism.

\section{DATA AND METHODS}

To understand the ways in which an art community views the business aspect of arts from the inside, we conducted open-ended, semi-structured interviews with galleries owners, artists, and others involved in the arts in a mediumsized Midwestern city. According to the local telephone directory, there were 21 art galleries, dealers, or consultants in the area, of which eleven were galleries. One of the listings was for a poster/print store, four were framers (though many of the galleries also offered framing services), another was an area arts council, and the other five were boutiques with some art available. The greatest concentration was in Art Space (pseudonym), which included six galleries during the time of the study, three of which were not listed in the directory (two opened shortly before we started the interviews). Two of the six galleries closed during the project. Other galleries have opened since then, there was one that moved, and other opened and closed.

Our interviews included ten gallery owners, three practicing artists, including one who was connected with a local art organization, an individual with another local art group, an owner of space in Art Space that housed a gallery, and another individual who was on the board of a local art group but not a practicing artist. We concentrated our efforts in Art Space, as well as Brick Town (pseudonym), which also has six galleries (with a seventh in the city proper but away from the central area). We interviewed owners/ managers in all six Art Space galleries, and four of the Brick Town galleries. One of the Brick Town galleries moved to a smaller location outside the area during the study (and has since closed).

The interviews focused on three areas of inquiry. First, we asked interviewees to describe the local art community. This was used as an ice breaker question, though we had met most of the interviewees prior to the interviews to establish rapport. We then asked about the role of the arts in urban sustainability in the area, as well as governmental/local support. We finished by asking about art and social discourse, and whether their customers were interested in a wide range of art. Most interviews lasted approximately 45 minutes, ranging from a half-hour interview that was interrupted because of customers (all interviews with gallery owners were conducted at their places of business) to an hour-and-a-half interview with a gallery owner that was leaving the area. All but three of the interviews were taped and transcribed. Three of the interviews were reconstructed using field notes written immediately after the interview.

\section{ANALYSIS}

Given the openness of the interviews, topics of discussion ranged from our actual research questions to networks of local people and groups who should be involved 
in the arts to America's fascination with oral sex. We will keep our focus on urban sustainability and social engagement, as these led to discussions about what kind of art was feasible for a gallery in this small market. It should be noted that we do not intend to generalizing our study to other small art markets. Instead, we hope to provide a map of the concerns people who are on the business side of the arts have about staying afloat.

\section{Urban Sustainability and Staying in Business}

As mentioned, the arts have been found to be effective in creating and maintaining interest in urban areas [1]. To develop rapport with the gallery owners and artists (though we had been working with some of them for some time), we asked a question about art in the area. Responses ranged from saying there was a high level of community appreciation, to customers seeking avant-garde work, to all of it being pretty dull. What was typical for all interviewees was a lament on the lack of art education in the area, both on a formal basis (in the schools) and informal, such as taking community art classes or even exposing oneself to the arts. The following is a typical response to this question:

[Art in this area] is in its primordial stages.... I could see it definitely growing, but it's taking a lot of education to grow, because so many people...they don't even go to art museums when they go out of town, let alone exploring the arts in schools or as they're growing up, or as adults when you are factory workers. It's a long way to go. (Interview, Gallery Owner)

Another ex-gallery owner discussed how wives would enter his gallery while husbands would wait at the door. His interpretation of this hesitation was that the men were afraid "of looking stupid." Even the gallery manager who said that there was a lot of great art in the area argued that not enough was being done to educate the public, especially in the primary schools, and that people did not explore parts of the gallery for fear of showing their ignorance. This seemed to be a major obstacle for the galleries, and rightly so, as people who were unwilling to enter the galleries would be unlikely to buy anything. This led to front windows being filled with craft items such as glass balls, greeting cards, and candle holders, which would be much more recognizable to potential customers. This is a point that should not be overlooked. While all the galleries had various ways to promote themselves in the local media, galleries that looked high class often found their doors empty relative to those galleries which had made a point of placing non-threatening (and affordable) things in the window. One of the galleries that closed during this project had taken such a selective approach, and found out too late that it needed to start carrying more affordable items that would be familiar to a larger portion of the population.

What is interesting is that a conversation with an individual working within a community organization had a completely different take on the situation, at least in the beginning. We were told that the area was thriving, and that the gallery walks were getting more crowded. However, when we asked how many galleries were in the area, we were told, "oh, probably about six or seven. What you see is that when one closes, another opens up." Given that the longest tenure of any of the galleries in that area was about five years, and that the number of galleries was not growing, there seemed to be a disconnect between the reality on the street and this individuals interpretation.

Following these questions, we asked how consumers navigated the gallery areas. Given that foot traffic in the area was the life blood of the galleries, we thought the gallery owners would have some idea of the local traffic patterns. This was not the case. The following was probably the most eloquent response:

Everybody [here] knows everybody else. And, as a matter of fact, when it's really, really busy during the summertime, we had, you know, and I don't know how formal this ever became, but, you know, those of us who were the closest friends would virtually draw a map. "Now, you walk right out here and you go to [that boutique]. And, then you've got to investigate [a restaurant].”...It depends on who was open at that particular time. I tell everybody everything, and I think a lot of my neighbors do the same thing....And, so I support other galleries, the other galleries support me. (Interview, Former Gallery Manager)

What sounds like a community effort, and people did not know each other in the area, seemed more like a cover for not really understanding the ways in which people were shopping. Most responses to the question of whether or not the galleries are the major draw sounded something like "...we get fifty/fifty. We pull some people in, while the other businesses bring in people who then see the galleries." (Gallery Owner) Another gallery owner told us that as many people, if not more so, are making a mad dash into the gallery to buy a wedding present as coming to see the featured art. Also, the idea of a close knit community was called into question when promotions for a show that was meant to bridge galleries in different locations caused problems between groups aligned with the various galleries. No one, it seemed, could be listed last. At the same time, none of the actors made mention that the promotion was something that would not have happened if it had not been for this specific show, so everyone was actually benefitting. This zero sum game approach to the market seemed prominent, as more informal discussions elucidated distrust among actors who had told us that everyone "is in this thing together." Those who had tried to get galleries to purchase shared advertising were often shunned and thought of as trying to promote themselves at the expense of others. We had at least three people from different galleries mention that they had tried to get people to work together, only to be ignored. When this project started, we found a few doors closed because of who we had talked to previously. In such a small community, information travels very quickly.

The need to purchase gifts, and the fact that these gallery owners did not have a good idea of what was drawing their consumers into the area (the two areas contained numerous other shops, such as restaurants and clothing stores), was evident in the items that were for sale. All of the galleries we visited carried everything from greeting cards costing a few 
dollars to paintings and sculptures priced at a few thousand dollars. The individual who had talked about drawing a map for customers insisted that the best performing gallery in the area was barely a gallery given all the "other stuff" that it carried. As with the discussion about the front windows earlier, this is what was perceived as marketable in the area.

It may be unsurprising that small business owners are unaware of where customers are coming from and what is bringing them to a specific area of the city, given their lack of economic and cultural resources. When asked about support from the larger community, most of the interviewees stated that while the city had been giving a great deal of lip service to beautifying the city, not much had come their way in terms of real support (which typically meant money). Foundations were also absent from the area. In fact, when talking with an individual who had real estate holdings in one of the areas, we were told that while there was a good deal of support for the arts in the community, none of the families with "old money" had ever developed a passion for local art. A historical house that is tied to one of the old names in the area sponsors an art walk every month, but even that has not been welcomed with open arms from the board members. There is a concern that the artists or the public will damage the house.

One other point should be made about the business practices of these galleries that was not part of the original interview questions, but became apparent very early in the interviews. Many of these galleries are not selling enough art to support their businesses. Instead, they relied heavily on the one thing they could offer people who had purchased art somewhere else - framing. Four of the galleries we spoke with did not offer framing, though one offered art and craft classes to help pay the rent, and two that had just opened mentioned that framing was a possibility in the future if they could find the right person to do it. The fourth gallery was a non-profit gallery, and the manager sent customers in need of framing to a smaller gallery had just opened nearby that was focusing on framing.

Framing was not only important in bringing in money, but also in the aesthetics of the shop. Displaying a variety of frame styles, as well as framing some of the pieces in the gallery, was felt to help maintain customers. As one gallery owner and framer mentioned,

I have had several [people]. . . who came here just for framing. They made some calls, and ended up here. And, we spent five hours on that first framing project. And, it cost under a hundred dollars to frame it, but they learned what they needed to do. And then they looked at things in the gallery to get an idea of what they like. And, they've been back ever since. And, I think that's just part of that catching them, and hitting them when they come in.

By providing framing and making it part of the business's atmosphere, this gallery owner had provided an incentive for new customers to look around the shop. If the only objectification of the gallery for certain customers is its framing display, that is still an introduction into the gallery that is expected to turn into more sales (either through the purchase of merchandise or other framing projects).

\section{Social Engagement}

The genesis for this project was an interest in art that was socially engaged, such as that created and promoted by the Dadaists [11]. By social engagement, we mean art that takes on social issues, such as gender inequality, sexual orientation, racism, and abortion. While we were hoping this kind of art would foster discussions within the community about controversial social issues, the "engagement" piece was about the interactions between artists and social issues. It was understood in the beginning of the project that socially engaged art was not typical gallery fare in the area. Instead, we wanted to know if anyone had ever tried to sell socially engaged art, and if not, why not. We were also hoping to find a gallery that had tried to carry socially engaged art to see not only if it was marketable but what kind of response they saw in their customers.

Some of our early conversations on this topic with gallery owners and artists did not bode well for a project focusing on art as social/political voice. We were told that some galleries and some artists had tried to create and sell socially engaged art, but they could not make a living from it, and one gallery owner told us that someone had asked her to take down a "Make Love Not War" poster displayed in her window. One gallery owner who was trying to carry a line of political cartoons said, "the political stuff sold like hot cakes, apparently, in Texas where the artist was originally from. I can't sell it here. It just sits there, and people look at it. But, it's not what they're interested in."

It was found that we were actually naive thinking that all gallery owners and artists would be interested in art that challenged the social landscape. One gallery owner said that everything was socially engaged, and artists should be allowed to just make beautiful art. Another artist stated:

I hate that kind of stuff. And, remember, I was a flower child of the ' $60 \mathrm{~s}$, and it didn't change anything. I remember going to a Yoko Ono performance in London -- what a waste. There was a big white sheet nailed to a wall with a ladder that you could climb on. When you got to the top of the ladder, there was a message that said, "you are here." Did I need to be told that? Art like that makes it difficult for real artists to compete. (Field Notes)

This should not have been too surprising, given that we were aware of artists such as Picasso who said that art should be about discovery, not research [27]. Still, we were thinking that artists would be heavily involved in various social issues. One artist, who had been successful selling in this particular market said, "I don't think [this area] fosters anything new.... I think this is a place that largely lives in the past, and I think that's reflected in the art and the artists of the place."

This split between those who wanted socially engaged art in the environment and those who did not was somewhat tempered by the demand in the market for titles. In talking with one of the gallery owners who is also a photographer, we were told that

I guess it's because of the times and the ways art has been presented to the general public, but 
everybody's looking for the meaning. "What do you mean by this?"..."Why did they do pastels of two dogs like that, I wonder what that means?" Or the, Thinking Red, Doing Red, Being Red, "What does that mean?" "What is he saying about that?" The Gorilla, "what does that mean?" Or The Whooping Cranes. "What does that mean?" And, the pudgies, "what does he mean by that?" And my own opinion is I'm sick and tired of hearing that. . .I'm not trying to make any kind of a social statement about anything. I'm not a photo journalist in that sense. I'm not trying to produce the ultimate photograph that is going to impact the lives of every person that looks at it. Like that famous Vietnam picture with the guy shooting the guy in the head, or the young woman, Vietnamese girl running down naked, running away from the fire bombing and all that. That's a whole different genre....

According to this artist, audience members are expecting meaning through titles, as well as narratives. This individual, while arguing that titles are often meaningless or done after the fact to impress customers, still had to find a justification for not having titles, or creating photographs that were not socially engaged. He was trying to move his audience from a civic order of worth - social meaning -- to one based on inspiration -- aesthetics.

There seemed to be two conflicting ideas within this market. First, there was a sense that there was little demand for art that was obviously socially engaged. Those gallery owners and artists that could talk about this kind of art selling elsewhere found it difficult to maintain even a portion of a gallery on the proceeds in this market. Second, most of the people we talked with discussed the importance of titles for the audience - titles that were not necessarily obvious, such as Blue Coneflower. Instead, it might be more profitable to call it something like, Blue Coneflower on the Edge of the Environmental Abyss. This is not a new or unique phenomenon, as others [16] have found that the story behind the art is often as important, if not more so, than the art itself to those who are making the purchases.

\section{A Note about the Art(ists)}

The final component of this research project was an art show featuring socially engaged art, and we thought the reader might be interested in what kind of art would be entered into this type of show given the description of the market provided above. The call for artists was general and statewide, asking artists to look for answers to social issues in their work. We sent out over 1000 entry forms, including individual artists, art collectives, college art departments, and some galleries. Artists could enter up to three pieces in any medium, with the only stipulation that the piece must be able to fit through the door of the gallery. Just over one hundred artists entered pieces, of which about 80 were chosen for the show from a panel of five jurors with art backgrounds (it should also be noted that a number of letters sent to galleries were returned unopened due to the business being closed).
The research team was given the opportunity to watch and take notes during the jury process.

The art ranged from abstract paintings and photo collages to quilts and sculptured penises. From an outsider's perspective, the jury seemed to be as much concerned about shock value (the sculptured penis made it into the show though the quilt did not) as about aesthetic value or the theme of the show. In talking with the jurors afterwards, there was a consensus that the best art pieces were now part of the show, and that we as non-artists did not have a good sense of how to judge such things when we asked why certain pieces had been accepted.

In terms of the market, the manager of this gallery was concerned about public reaction to some of the pieces, and there was little talk about any of the pieces selling (we were not given prices for these works). Instead, it was hoped that the publicity for the show would bring more people into the gift area of the gallery, where merchandise was both more traditional and more affordable. The dialectic in this case is to exhibit high priced but controversial art in one area, and then have people feel more comfortable in the gift shop. This is more of a Hegelian process in the sense that something can only be labeled relative to its opposition. In this case, "good" art is recognizable and affordable in comparison to the "bad" art that is high priced and politically incorrect.

This notion of non-sellable art is backed by a conversation we had with one of the artists who entered a piece into the show that was rejected. The piece took on the issue of sexual orientation, and was something that the artist had been concerned with in terms of showing in this market. This particular show offered a way around those concerns. The artist, who had other, noncontroversial work displayed in the area, said that he thought about how he categorized various pieces based on perceived local expectations.

I've learned how to compartmentalize...I'm not a compartmentalized person. I actually find it, you know, the antithesis of integrity. But, it's required to make a living in the arts. Every artist I know who makes a living, and they call it the A-line and the B-line. You know, the A-line is the stuff that is a hole in your soul poured out manifest. And, the B-line is what people want. And, then we die, if we're lucky, the A-line supplants the B-line. (Interview)

This is an old story, and can be applied to one of the researchers of this project. As a practicing artist, this individual's spouse was constantly being told that the art would be worth much more after the researcher/artist was dead, as it instantly brings about scarcity of the artist's work. While this is true for some artists, such as Van Gogh, it also shows a very traditional way of thinking about the value of art - do not buy until it is worth something.

The show, which was carried by two galleries between May 2008 and August 2008, and titled "Social Discourse: A visual arts experience," gave us an opportunity to survey visitors to measure attitudes toward art. Survey questions 
ranged from ideas about art forms to pieces that did not belong in the show. We were able to collect 114 surveys, of which 110 respondents answered a question about how important the arts were for the local economy. This question was meant as a proxy for the potential of purchasing art. Of these respondents, $60.9 \%(n=67)$ felt that art was very important for the economy, $32.7 \%(n=36)$ felt it was somewhat important, and only $6.4 \%(n=7)$ thought it was not important. Given our interest in the negotiation of art space, these findings highlight the fact that when people are visiting art galleries even in a smaller market, they are aware of the economics of art. Even if they are not purchasing at that time, it is an aspect of their understanding of how a gallery operates.

\section{CONCLUSIONS}

According to Elizabeth and Young [13], "[community] is born ... out of a deep and natural passion to make the world a better place for those we cherish - a healthier, more congenial place, where we can grow and express who we really are or who we'd like to be." The stories presented by these authors and their contributors come from places like New York City and Minneapolis, places that have a history of promoting and supporting the arts. There are also places like Corvallis, OR and Machias, ME which do not. Can we assume that every community has such a background in terms of interest in the arts? According to the people we spoke with in this one Midwestern city, art and community do exist, but not necessarily in conjunction with each other. We did hear a few comments about the community's pride in the arts, but more often were told that most of the galleries were having a hard time (or had in the past), that people were fearful of the arts, the schools had stopped teaching the arts, and the local government had not provided sufficient support to make the arts feasible and sustainable.

To be viable businesses, most of the galleries had diversified both in terms of the kind of art that was displayed and by carrying inexpensive gifts such as greeting cards, jellies, fingernail files, and mobiles, with many also involved in framing. While there seemed to be a focus on local artists in most of the galleries, there was a good deal of merchandise from outside the area (including items from outside the country). This is not a value judgment, but simply an observation of what it took to make it in a small art market. McCall [3] argued that the St. Louis art market - which he referred to as small -- had to rely on the art being produced at local colleges and universities to survive, yet this market was missing even that. One gallery had hosted a show featuring art from local college students, and not one piece was sold. What did sell during that time was pottery and greeting cards - pragmatic items in a seemingly traditional market.

The potential vitality of the market may have been strengthened by galleries developing stronger linkages with each other. While there did seem to be some superficial linkages, there existed a larger concern that if one gallery succeeded, it came at the cost of other galleries floundering. This zero sum game, where one gallery opens as soon as another closes is likely to keep this market small and struggling.
Finally, art has been used as a voice to challenge social boundaries and issues [28], though many of these stories come from large markets such as Los Angeles, London, and Paris. Socially engaged art can be found in small markets, though our experiences showed that this may involve little more than caricatures of political figures, art that does not sell, or art with veiled messages. Art in public arenas is not just about what artists have to say; it is also about what artists are able to sell.

\section{ACKNOWLEDGEMENTS}

Partial funding for this project was provided by the College of Social Sciences at Michigan State University, and Michigan State University's Office of the Provost.

\section{REFERENCES}

[1] Miles S, Paddison R. Introduction: the rise and rise of culture-led urban regeneration. Urban Stud 2005; 42 (5/6): 833-9.

[2] Quinn B. Art festivals and the city. Urban Stud 2005; 42 (5/6): $927-$ 43.

[3] McCall MM. Art without a market: creating artistic value in a provincial world art world. Symbol Interact 1977; 1 (1): 32-43.

[4] Becker HS. Art Worlds. Berkeley, CA: University of California Press 1982.

[5] Barnes M. How to get hung. Rutland, VT: Journey Editions1994.

[6] DiMaggio P. Culture and economy. In: Smelser NJ, Swedberg R, Eds. The Handbook of economic sociology, Princeton, NJ: Princeton University Press 1994; pp. 27-57.

[7] Bourdieu P. Distinction. (trans by Nice R). Cambridge, MA: Harvard University Press 1984.

[8] Lamont M, Fournier M, Eds. Cultivating differences. Chicago: University of Chicago Press 1992.

[9] Dewey J. Art as experience. New York: Perigee 1934.

[10] King R. The Judgment of Paris. New York: Walker 2006.

[11] Richter H. Dada. London, UK: Thames and Hudson 1964.

[12] Hopkins D. Dada and surrealism. New York: Oxford University Press 2004.

[13] Elizabeth L, Young S, Eds. Works of heart. Oakland, CA: New Village Press 2006.

[14] DiMaggio P. Cultural aspects of economic action and organization In: Friedland R, Robertson AF, Eds. Beyond the marketplace, New York: Walter de Gruyter 1990; pp. 113-36.

[15] Berger PL, Luckmann T. The social construction of reality. Garden City, NY: Doubleday 1966.

[16] Fine GA. Everyday genius. Chicago: University of Chicago Press 2004.

[17] Hogg MA, Abrams D. Social identifications. New York: Routledge 1990.

[18] Boltanski L, Thévenot L. The sociology of critical capacity. Eur J Soc Theory 1999; 2(3): 359-77.

[19] Boltanski L, Thévenot L. The reality of moral expectations: a sociology of situated judgment. Philos Exp 2000; 3(3): 208-31.

[20] Boltanski L, Thévenot L. On justification. (Translated by Porter C). Princeton, NJ: Princeton University Press 2006.

[21] Walzer M. Spheres of Justice. New York: Basic Books 1983.

[22] Clark T. Art and propaganda. New York: Harry N. Abrams 1997.

[23] Schonfeld S, Reinstaller A. The effects of gallery and artist reputation on prices in the primary market for art: a note. J Cult Econ 2007; 31:143-53

[24] Shubik M. Dealers in art. In: Towse R, Ed. A Handbook of Cultural Economics. Cheltenham, UK: Edward Elgar 2003; pp.194-200.

[25] Evans G. Measure for measure: evaluating the evidence of culture's contribution to regeneration. Urban Stud 2005; 42 (5/6): 959-983 
[26] Atkins R, Mintcheva S, Eds. Censoring culture. New York: W.W. Norton 2006.

[27] Chipp HB. Theories of modern art. Berkeley, CA: University of California Press 1968.
[28] Archer M. Art since 1960, $2^{\text {nd }}$ ed. London, UK: Thames and Hudson 2002.

(C) Ten Eyck et al.; Licensee Bentham Open.

This is an open access article licensed under the terms of the Creative Commons Attribution Non-Commercial License (http://creativecommons.org/licenses/by$\mathrm{nc} / 3.0 /$ ), which permits unrestricted, non-commercial use, distribution and reproduction in any medium, provided the work is properly cited. 